\title{
Hemoperitoneo masivo consecutivo a perforación espontánea de la vesícula biliar. A propósito de una caso de muerte súbita.
}

Massive hemoperitoneo secondary to spontaneous perforation of gall bladder. Report of a case presenting as sudden death.

P.M. Garamendi y col.

Cuad Med Forense 2002; 28:37-41

En este trabajo se presenta un caso de hemoperitoneo masivo consecutivo a perforación espontánea de la vesícula biliar, asociada a colelitiasis, obstrucción del conducto cistico y colecistitis aguda hemorrágica que produjo como primera manifestación la muerte súbita en un varón adulto. En la literatura medica este tipo de situación clínica y anatomopatológica es excepcional. Los casos descritos de perforaciones espontáneas de la vesícula biliar con hemoperitoneo asociado son menos de 50 desde 1858. Desde 1952 solo existe otra referencia de 199| de un hallazgo similar, aunque no asociado a colelitiasis, como causa de muerte súbita.

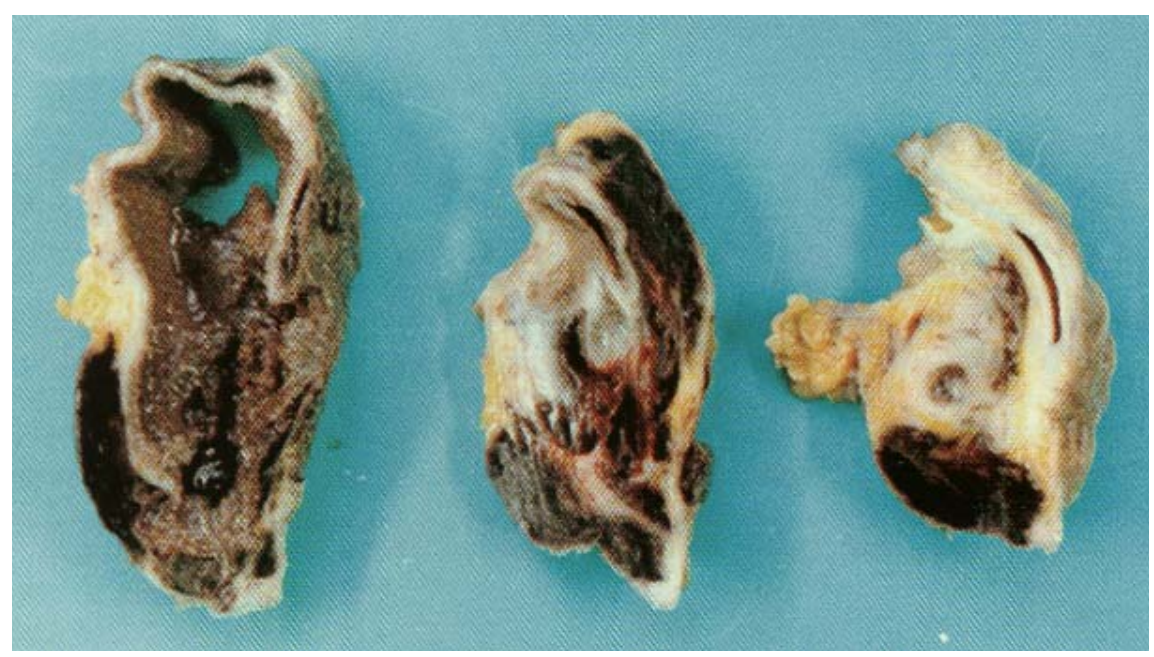

Figura 1.- Corte seriado de la vesícula biliar. 